\title{
PARASITES IN THE THORACIC GANGLION of Pachygrapsus marmoratus (Brachyura: Grapsidae) FROM THE COAST OF PORTUGAL
}

\author{
KURIS A.M.*, TORCHIN M.E.* \& LAFFERTY K.D.**
}

\begin{abstract}
Summary:
We examined 149 marbled shore crabs, Pachygrapsus marmoratus, from the coast of Portugal for parasites. In particular, we focused our effort on the crab thoracic ganglion. The thoracic ganglion is the largest concentration of nervous tissue in a crab and thus, parasites associated with this organ are well situated to influence host behavior. We found metacercariae of two microphallid trematode species in the thoracic ganglion. We also found a microsporan and an apicomplexan associated with the thoracic ganglion. Other parasites not associated with the thoracic ganglion included gregarine trophozoites which were present in the digestive diverticulae in some of the crabs and the entoniscid isopod, Grapsion cavolini. Metacercariae of one of the trematodes (probably Microphallus pachygrapsi (Deblock and Prevot)l, may influence the mortality of its host.
\end{abstract}

KEY WORDS : Pachygrapsus marmoratus, shore crab, parasite, trematode, metacercaria, thoracic ganglion, Grapsion cavolini, Microspora.

I

n the course of an investigation into the host specificity of the rhizocephalan barnacle, Sacculina carcini, for Carcinus maenas and Pachygrapsus marmoratus (Kuris et al., submitted), we had occasion to examine two populations of P. marmoratus on the coast of southern Portugal for parasites. The most distinctive aspect of this study was a careful examination of the thoracic ganglion for parasites. Few, if any, studies of any crustacean have excised and carefully examined the thoracic ganglion for parasites. We also report on other parasites found in a general examination of the hemocoel.

\section{MATERIALS AND METHODS}

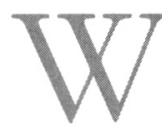

e examined 71 P. marmoratus from the Mira River estuary (60 from Furnas - southern shore and 11 from Vila Nova de Milfontes

\footnotetext{
* Marine Science Institute and Department of Ecology, Evolution and Marine Biology, University of California, Santa Barbara, 93106, USA. ** Western Ecological Research Center, USGS, c/o Marine Science Institute, University of California, Santa Barbara, 93106, USA. Correspondence: Armand M. Kuris.

Tel. : 805-893-3998 - Fax : 805-893-4724.

E-mail : kuris@lifesci.ucsb.edu
}

Résumé : PARASITES DU GANGLION THORACIQUE DE PACHYGRAPSUS Marmoratus (BRachyURA: GRAPSIDAE) DE LA CÔTE dU PORTUGAL Nous avons examiné 149 crabes marbrés, Pachygrapsus marmoratus, en provenance de la côte du Portugal à la recherche de parasites. En particulier, nous avons concentré nos efforts sur le ganglion thoracique de ces crabes. Le ganglion thoracique est la plus importante concentration de tissus nerveux chez le crabe et les parasites présents dans cet organe sont donc à même d'influencer le comportement de l'hôte. Nous avons trouvé des métacercaires de deux espèces de Trématodes Microphallidés dans le ganglion thoracique. Nous avons aussi trouvé un Microsporidé et un Apicomplexa associés à ce ganglion. D'autres parasites, non présents dans le ganglion, sont des trophozoiltes de Grégarines observés au niveau du tube digestif de quelques crabes et de l'isopode Entoniscien Grapsion cavolini. Les métacercaires de l'un des Trématodes (probablement Microphallus pachygrapsi (Deblock and Prévot)l, peuvent influencer la mortalité de I'hôte.

MOTS CLÉS : Pachygrapsus marmoratus, crabe marbré, parasite, Trématode, métacercaire, ganglion thoracique, Grapsion cavolini, Microsporea.

- northern shore) and 78 from the tidepools of the rocky outer coast at Saõ Torpes, $\sim 20 \mathrm{~km}$ north of the Mira River estuary ( $5 \mathrm{~km}$ south of Sines). Crabs examined ranged in size from $7-30 \mathrm{~mm}$ carapace width (CW, measured inside the second pair of lateral spines). The carapace was removed, the hemocoel, digestive glands, gonads and the surface of the cardiac stomach and buccal musculature were inspected for parasites. After removing the digestive gland from the thorax, the nerves connected to the thoracic ganglion were severed, the ganglion removed and carefully examined with a compound microscope at $100 \times, 200 \times$ and $400 \times$ magnifications. All parasites detected were recorded. The metacercariae in the thoracic ganglia were counted.

\section{RESULTS}

Wwo species of trematode metacercariae were present in the thoracic ganglion at Saõ Torpes. Both appeared to be microphallids. The larger species had spherical metacercaria and was present in $33 \%$ of the crabs. The prevalence of this metacercaria significantly increased with increasing crab size $(\chi 2=$ 


\begin{tabular}{cccc}
\hline Size class & N & $\begin{array}{c}\text { Prevalence } \\
(\%)\end{array}$ & $\begin{array}{c}\text { Mean } \\
\text { intensity }\end{array}$ \\
\hline $7.0-11.9$ & 18 & 0 & - \\
$12.0-15.9$ & 21 & 33 & 4.9 \\
$16.0-19.9$ & 19 & 47 & 5.7 \\
$20.0-30.9$ & 20 & 50 & 3.2 \\
\hline
\end{tabular}

Size class is carapace width in $\mathrm{mm}, \mathrm{N}$ is sample size, prevalence is proportion of crabs infected, mean intensity is the number of metacercariae per infected crab.

Table I. - Prevalence and intensity of the large metacercariae in the thoracic ganglion of Pachygrapsus marmoratus at Saõ Torpes, Portugal.

18.6, $\mathrm{P}<0.005, \mathrm{~N}=78$ ), while its mean intensity did not (Table I). These metacercariae were highly aggregated among the crabs; $55 \%$ of the metacercariae were recovered from only three of the 26 infected crabs. The smaller species of metacercaria was also probably a microphallid, based on presence of a stylet. Their volume was only about one-tenth that of the larger species. They were present in only $6.4 \%$ of the crabs from Saõ Torpes and had a maximum intensity of only two cysts per crab.

A few small packets of microsporan spores were present in the thoracic ganglia of several crabs from both the Mira River estuary (7\%) and at Saõ Torpes (4\%). None were found in crabs greater than $20 \mathrm{~mm}$ CW. No evident pathology was associated with these light infections. Additionally, two black ovoid bodies with naked apicomplexan sporozoites were found in a single crab (male, $16 \mathrm{~mm}$ carapace width) from Saõ Torpes.

The entoniscid isopod, Grapsion cavolini, was the only metazoan parasite not associated with the thoracic ganglion. It was present at a prevalence of $18 \%$ at Vila Nova de Milfontes in the Mira River estuary and on the outer coast at Saõ Torpes at a prevalence of $5 \%$. All infected crabs had a single infection with the exception of one double infection in a crab at Saõ Torpes. All parasitized crabs were greater than $16 \mathrm{~mm}$ carapace width. We also observed (but did not quantify) gregarine trophozoites in the digestive diverticulae in crabs from Saõ Torpes.

\section{DISCUSSION}

Whis is the first report of parasites of Pachygrapsus marmoratus from the coast of Portugal. Grapsion cavolini has been reported from other Atlantic and Mediterranean populations of P. marmoratus (Bourdon, 1964; Perez, 1933). We did not find the rhizocephalan barnacle, Sacculina benedeni, in our samples. It has been reported from Mediterranean populations (Perez, 1933) but does not appear to infect $P$. marmoratus from the Atlantic coast. The large microphallid is morphologically similar to and is probably Microphallus pachygrapsi (Deblock and Prevot) (Prevot, 1971). Near Marseille, its final host is the gull, Larus argentatus, and its first intermediate host is Vermetus triqueter (Prevot, 1971). We are unable to further identify the uncommon small microphallid and the apicomplexan. The gregarine is Cephaloidophora conformis (Deising, 1851) and is often found in the digestive diverticula of P. marmoratus (Vivarès, 1972; Vivarès \& van Wormhoudt, 1976).

This investigation is the most extensive examination for parasites of the thoracic ganglion of any crustacean. Our findings suggest that this may be an important organ to examine in other crabs. The thoracic ganglion is the largest concentration of nervous tissue in a crab and parasites located in this organ may be well-situated to influence the behavior of infected crabs. Although our data are insufficient for a definitive analysis, it is possible that the metacercariae in the thoracic ganglion may influence the susceptibility of these crabs to predation by their avian final hosts. Prevalence of $M$. pachygrapsi increases with crab size, showing that larger crabs are susceptible to this parasite, but intensity does not similarly increase. This suggests that heavily infected crabs may be experiencing a higher mortality than are crabs with less intense infections. Further studies are necessary to fully evaluate this hypothesis.

\section{ACKNOWLEDGEMENTS}

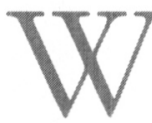

e thank Drs Teresa Cruz and Joaõ Castro of the Universidade de Evora Marine Laboratory in Sines for their hospitality, use of facilities and sharing their knowledge of the local fauna, Patricia Sadeghian for her assistance with field work on a preliminary trip to the area and Morgana Mongraw-Chaffin for translating the summary. This research was funded by a grant from the National Sea Grant College Program, National Oceanographic and Atmospheric Administration (NOAA), US Department of Commerce under grant number NA06RG0142, project number R/CZ-162 through the California Sea Grant College system, and in part, by the California State Resources Agency. The views expressed herein are those of the author and do not necessarily represent the views of NOAA or any of its sub-agencies. The US government is authorized to reproduce and distribute this paper for governmental purposes.

\section{REFERENCES}

BOURDON R. Épicarides et rhizocéphales du Bassin d'Arcachon. Extrait des Procès-Verbaux de la Société Linnéenne de Bordeaux, 1964, 101, 1-7. 
KurIs A.M., TORChin M.E. \& LAFFerTy K.D. An experimental evaluation of host specificity: the role of encounter and compatibility filters for a rhizocephalan parasite of crabs. International Journal for Parasitology (submitted).

PEREz C. Action de la sacculine sur les caractères sexuels extérieurs de Pachygrapsus marmoratus. Comptes Rendus des Séances de la Société de Biologie et de ses Filiales, 1933, 113, 1027-1029.

Prevot G. Contribution à l'étude des Microphallidae Travassos, 1920 (Trematoda). Cycle évoltif de Microphallus pachigrapsi Deblock et Prevot, 1969, parasite du Goéland à pieds jaunes (Larus argentatus). Annales de Parasitologie Humaine et Comparée, 1971, 46, 453-461.

VIVARÈs C.P. Parasitism in Brachyura (Crustacea, Decapoda) of French Mediterranean Coast and lagoons of LanguedocRossillon. Vie et Milieu, Serie A - Biologie Marine, 1972, 23, 191218.

VIVARÈs C.P. \& VAN WORMHOUdT A. Sur la nutrition glucidique chez Cephaloidophora conformis (Sporozoa, Gregarinia), parasite digestif du Branchyoure Pachygrapsus marmoratus. Comptes Rendus des Séances de la Société de Biologie et de ses Filiales, 1976, 170, 71-77

Reçu le 16 février 2004 Accepté le 10 juin 2004 